\title{
Fermentation of Mannitol Extracts From Brown Macro Algae by Thermophilic Clostridia
}

\author{
Theo Chades, Sean M. Scully, Eva M. Ingvadottir and Johann Orlygsson* \\ Faculty of Natural Resource Sciences, University of Akureyri, Akureyri, Iceland
}

Mannitol-containing macro algae biomass, such as Ascophyllum nodosum and Laminaria digitata, are a potential feedstock for the production of biofuels such as bioethanol. The purpose of this work was to evaluate the ability of thermophilic anaerobes within Class Clostridia to ferment mannitol and mannitol-containing algal extracts. Screening of the type strains of six genera, Caldanaerobius, Caldanaerobacter, Caldicellulosiruptor, Thermoanaerobacter, Thermobrachium, and Thermoanaerobacterium) was conducted on $20 \mathrm{mM}$ mannitol and revealed that 11 of 41 strains could utilize mannitol with ethanol being the dominant end-product. Mannitol utilization seems to be most common within the genus of Thermoanaerobacter (7 of 16 strains) with yields up to $88 \%$ of the theoretical yield in the case of Thermoanaerobacter

OPEN ACCESS

Edited by:

Nils-Kaare Birkeland,

University of Bergen, Norway

Reviewed by:

Hugh Morgan,

University of Waikato, New Zealand Sachin Kumar,

Sardar Swaran Singh National Institute of Renewable Energy, India

*Correspondence:

Johann Orlygsson jorlygs@unak.is

Specialty section:

This article was submitted to

Extreme Microbiology,

a section of the journal

Frontiers in Microbiology

Received: 28 April 2018

Accepted: 30 July 2018

Published: 20 August 2018

Citation:

Chades T, Scully SM, Ingvadottir EM and Orlygsson J (2018) Fermentation of Mannitol Extracts From Brown

Macro Algae by Thermophilic

Clostridia. Front. Microbiol. 9:1931. doi: 10.3389/fmicb.2018.01931 pseudoethanolicus. Six selected mannitol-degrading strains (all Thermoanaerobacter species) were grown on mannitol extracts prepared from $A$. nodosum and $L$. digitata. Five of the strains produced similar amounts of ethanol as compared with ethanol yields from mannitol only. Finally, T. pseudoethanolicus was kinetically monitored using mannitol and mannitol extracts made from two macro algae species, A. nodosum and L. digitata for end-product formation.

Keywords: third generation biomass, bioethanol, Thermoanaerobacter, seaweed, bioprocessing, extremophiles, Ascophyllum nodosum, Laminaria digitata

\section{INTRODUCTION}

Due to the worldwide energy crisis and environmental problems associated with the utilization of petroleum products, the need for biofuel production from renewable feedstocks that do not compete with agriculture has been of increased interest over the past several decades (Sánchez and Cardona, 2008; Scully and Orlygsson, 2015). While the production of bioethanol from lignocellulosic biomass has made advances in terms of pretreatment of the biomass and the development of microorganisms well-suited to this task, substantially less work has been done on the utilization of marine biomass, such as macro algae, as a raw material. The utilization of macro algae (third generation biomass) as a feedstock is of special interest as marine biomass often has high productivity and does not compete with arable land (Daroch et al., 2013; Wei et al., 2013). The utilization of third generation biomass remains challenging due to the diversity of chemical compositions of macro algae and as well as lack of well-established methodologies for the saccharification of this type of biomass (Daroch et al., 2013). While macro algae do not contain lignin like terrestrial plants, many macro algae contain phlorotannins which are similarly structured to lignin in that it is composed of phloroglucinol, an aromatic 
molecule (Kawai and Murata, 2016). Brown macro algae have complex carbohydrate composition containing alginate, fucoidan, mannitol, and laminarin (Wei et al., 2013; Xia et al., 2015; Kawai and Murata, 2016). Mannitol and laminarin function as reserve carbohydrates and are accumulated during summer months of the northern hemisphere (Adams et al., 2011) reaching concentrations as high as $25-30 \%$ on a dry weight basis (Daroch et al., 2013; Wei et al., 2013). Brown macroalgae are harvested commercially in large quantities in Asia and Europe (Muty and Banerjee, 2012). In 2012, 24 million tons of macro algae were harvested globally with only a handful of nations responsible indicating that there is great potential to exploit these materials (Radulovich et al., 2015). In the west of Iceland, Laminaria digitata and Ascophyllum nodosum have been dried using geothermal heat since the 1970s which was commercialized by Thorverk, ehf in the mid-1980s although harvested quantities are less than 20 tons per year. As a raw material for bioprocessing, brown macro algae have been used for biogas production while for bioethanol production the complexity of the biomass still presents a serious challenge for economic success due to the diversity of carbohydrates present as well as pretreatment methodologies still being in their infancy (Wei et al., 2013; Enquist-Newman et al., 2014; Milledge et al., 2014; Jiang et al., 2016).

Thermophilic species within Class Clostridia, including genera such as Caldicellulosiruptor, Thermoanaerobacter, and Thermoanaerobacterium, have been isolated from a wide range of thermal environments including many in terrestrial geothermal areas in Eurasia including Iceland, and the Kamchatka Peninsula, Russia (Burgess et al., 2007). As with thermoanaerobes in general, work at higher operating temperatures improves substrate solubility and reduces viscosity, improves the thermodynamics of many fermentative processes, and could potentially allow for in situ distillation of volatile end products such as ethanol. Many thermophilic Clostridia are of interest for their inherent tolerance to extreme environmental conditions and their ability to produce potential biofuels from a broad range of substrates including monosaccharides present in lignocellulosic biomass although highly reduced sugar alcohols have received little attention. Many of these thermophilic Clostridia also have the ability to degrade polymeric carbohydrates which often includes starch, xylan, and even crystalline cellulose (Ren et al., 2009; Taylor et al., 2009; Chang and Yao, 2011; Scully and Orlygsson, 2015). Several Caldicellulosiruptor species in particular are highly versatile bioprocessing platforms with diverse capabilities involving the deconstruction of complex carbohydrates including cellulose and hemicelluloses (Blumer-Schuette et al., 2012; Carere et al., 2012). Due to the broad substrate spectra and diverse metabolic capabilities demonstrated by the aforementioned thermophilic anaerobes, they make natural prospecting candidates for the utilization of algal biomass, particularly mannitol. While the utilization of sugar alcohols, such as D-mannitol, are often reported in the work describing novel species, end product spectra are seldom reported.

Sugar alcohols, such as mannitol, are naturally occuring or can be produced by the catalytic dehydrogenation of their correpsonding hexose or pentose or can be produced by yeast during fermentation (Tanghe et al., 2005). Mannitol, in addition to being an inexpensive substrate, can be easily isolated from brown algae such as A. nodosum, Laminaria species, and Macrocystis pyrifera, such as sorbitol (glucitol), and mannitol. Beyond their applications as artificial sweeteners and laxatives, other potential applications of mannitol include clinical applications and as a fermentation feedstock (Daroch et al., 2013; Wei et al., 2013). Mannitol is interesting for biofuel production since its heating value is higher than that of glucose $(3025 \mathrm{~kJ} / \mathrm{mol}$ versus $2805 \mathrm{~kJ} / \mathrm{mol}$ ) and is a more reduced fermentation substrate as compared to hexoses and thus is an unexploited resource for bioethanol production (Daroch et al., 2013; Wei et al., 2013).

Mannitol utalization is a fairly ubiquitous trait with organisms including yeast such as Candida albicans and Pichia angophorae (Horn et al., 2000) although some strains of Saccharomyces cerevisiae have been adapted to utilize mannitol (Quain and Boulton, 1987). Mesophilic bacteria capable of mannitol utilization include Staphylococcus aureus, Escherichia coli (Kim et al., 2011), Zymobacter palmae (Horn et al., 2000), Vibrio tritonius (Matsumura et al., 2014), Clostridium butyricum (Heyndrickx et al., 1989), Clostridium difficile (Kazamias and Sperry, 1995), Clostridium acetobutylicum (Kaid et al., 2016), and Anaerobium acetethylicum (Patil et al., 2015). Thermophilic bacteria known to degrade mannitol anaerobically include the recently described Defluviitalea phaphyphila which is capable of degrading multiple macro algae components (Ji et al., 2016a,b), Caldicoprobacter algeriensis (Bouanane-Darenfed et al., 2011), Thermoanaerobacter wiegelii which yields ethanol (Cook et al., 1996), and Thermoanaerobacter pentosaceus (Sittijunda et al., 2013; Tomás et al., 2013).

As brown algae commonly contain high concentrations of mannitol, commercially harvested brown algae species such as $L$. digitata and $A$. nodosum make logical choices of raw material. Macrocystis pyrifera contains up to $12.4 \%$ mannitol by weight (Mateus et al., 1977) while the mannitol content in L. digitata has been found to vary between 3 and $21 \%$ (Black et al., 1952) although more recent reports have reported results above $30 \%$ on a weight basis (Adams et al., 2011). The extraction of mannitol from brown algae can be accomplished using solid-liquid extraction using weakly acidic solutions as has been reported for brown algae such as Macrocystis pyrifera (Mateus et al., 1977).

The present work examines the extraction of mannitol from macro algae and its subsequent fermentation to ethanol by thermophilic Clostridia. Comparisons between dilute acid solid-liquid extraction conditions under mild $\left(50^{\circ} \mathrm{C}\right.$ or less) conditions were performed. The ability of thermophilic Clostridia in the genera of Caldanaerobius, Caldicellulosiruptor, Caldanaerobacter, Thermoanaerobacterium, Thermoanaerobacter, and Thermobrachium to utilize mannitol as the sole substrate as well as mannitol extracted by dilute acid extraction from two ubiquitous mannitol-containing brown algae species, $A$. nodosum and $L$. digitata were tested. A kinetic experiment with a promising strain, Thermoanaerobacter pseudoethanolicus, was also performed. This study demonstrates the ease with which mannitol can be 
extracted and fermented to bioethanol from readily available brown algae.

\section{MATERIALS AND METHODS}

\section{Strains and Cultivation Conditions}

Organisms were cultivated in Basal Mineral (BM) medium prepared as previously described (Sveinsdottir et al., 2009) with modifications; the medium consisted of (per liter): $\mathrm{NaH}_{2} \mathrm{PO}_{4} \cdot 2 \mathrm{H}_{2} \mathrm{O} 3.04 \mathrm{~g}, \mathrm{Na}_{2} \mathrm{HPO}_{4} \cdot 2 \mathrm{H}_{2} \mathrm{O} 5.43 \mathrm{~g}, \mathrm{NH}_{4} \mathrm{Cl} 0.3 \mathrm{~g}$, $\mathrm{NaCl} 0.3 \mathrm{~g}, \mathrm{CaCl}_{2} \cdot 2 \mathrm{H}_{2} \mathrm{O} 0.11 \mathrm{~g}, \mathrm{MgCl}_{2} \times 6 \mathrm{H}_{2} \mathrm{O} 0.1 \mathrm{~g}$, yeast extract $2.0 \mathrm{~g}$, resazurin $1 \mathrm{mg}$, trace element solution $1 \mathrm{~mL}$, vitamin solution (DSM141) $1 \mathrm{~mL}$, and $\mathrm{NaHCO}_{3} 0.8 \mathrm{~g}$. The trace element solution consisted of the following on a per liter basis: $\mathrm{FeCl}_{2} \times 4 \mathrm{H}_{2} \mathrm{O} 2.0 \mathrm{~g}$, EDTA $0.5 \mathrm{~g}, \mathrm{CuCl}_{2} 0.03 \mathrm{~g}, \mathrm{H}_{3} \mathrm{BO}_{3}, \mathrm{ZnCl}_{2}$, $\mathrm{MnCl}_{2} \times 4 \mathrm{H}_{2} \mathrm{O},\left(\mathrm{NH}_{4}\right) \mathrm{Mo}_{7} \mathrm{O}_{24}, \mathrm{AlCl}_{3}, \mathrm{CoCl}_{2} \times 6 \mathrm{H}_{2} \mathrm{O}, \mathrm{NiCl}_{2}$, and $0.05 \mathrm{~g}, \mathrm{Na}_{2} \mathrm{~S} \times 9 \mathrm{H}_{2} \mathrm{O} 0.3 \mathrm{~g}$, and $1 \mathrm{~mL}$ of concentrated $\mathrm{HCl}$. The final mannitol concentration was $20 \mathrm{mM}$ in all cases. The medium was prepared by adding the buffer to distilled water containing resazurin and boiled for $10 \mathrm{~min}$ and cooled under nitrogen flushing $\left(<5 \mathrm{ppm} \mathrm{O}_{2}\right)$. The mixture was then transferred to serum bottles using the Hungate technique (Hungate, 1969; Miller and Wolin, 1974) and autoclaved for $60 \mathrm{~min}$. Media preparations containing algal extracts were sterilized by Tindallization to avoid browning of the media; these serum bottles were heated twice at $90^{\circ} \mathrm{C}$ for $60 \mathrm{~min}$. All other components of the medium were added separately through filter $(0.45 \mu \mathrm{m})$ sterilized solutions. All experiments were conducted at $65^{\circ} \mathrm{C}$ and at $\mathrm{pH}$ of 7.0 with a liquid-gas phase (L-G) ratio of $1: 1$ in which the gas phase consists of nitrogen. In all cases, experiments were performed in triplicate.

Forty one strains of thermophilic anaerobes from the genera of Caldicellulosiruptor, Caldanaerobacter, Thermoanaerobacter, and Thermoanaerobacterium were purchased from Deutsche Sammlung von Mikroorganismen und Zellkulturen (DSMZ); Thermoanaerobacterium thermostercoris (DSM 22141), Thermoanaerobacterium thermosulfurigenes (DSM 2229), Thermoanaerobacterium aotearoense (DSM 10170), Thermoanaerobacterium thermosaccharolyticum (DSM 571), Thermoanaerobacterium saccharolyticum (DSM 7060), Thermoanaerobacterium xylanolyticum (DSM 7097), Thermoanaerobacterium aciditolerans (DSM 16487), Caldanaerobius polysaccharolyticus (DSM 13641), Caldanaerobius zeae (DSM 13642), Caldanaerobius fijiensis (DSM 17918), Thermobrachium celere (DSM 13655), Caldicellulosiruptor changbaiensis (DSM 26941), Caldicellulosiruptor saccharolyticus (DSM 8903), Caldicellulosiruptor owensis (DSM 13100), Caldicellulosiruptor bescii (DSM 6725), Caldicellulosiruptor acetigenus (DSM 7040), Caldicellulosiruptor lactoaceticus (DSM 9545), Caldicellulosiruptor kristjanssonii (DSM 12137), Caldicellulosiruptor hydrothermalis (DSM 18901), Caldicellulosiruptor kronotskiensis (DSM 18902), Thermoanaerobacter acetoethylicus (DSM 2359), Thermoanaerobacter brockii subsp. brockii (DSM 1457), T. brockii subsp. finnii (DSM 3389), T. brockii subsp. lactiethylicus (DSM 9801), Thermoanaerobacter italicus (DSM 9252), Thermoanaerobacter ethanolicus (DSM 2246), Thermoanaerobacter kivui (DSM 2030), Thermoanaerobacter mathrani subsp. mathrani (DSM 11426), T. pentosaceus (DSM 25963), T. pseudoethanolicus (DSM 2355), Thermoanaerobacter siderophilus (DSM 12299), Thermoanaerobacter sulfurigignens (DSM 17917), Thermoanaerobacter sulfurophilus (DSM 11584), Thermoanaerobacter thermohydrosulfuricus (DSM 567), Thermoanaerobacter uzonensis (DSM 18761), T. wiegelii (DSM 10319), Caldanaerobacter subterraneus subsp. yonseiensis (DSM 13777), C. subterraneus subsp. subterraneus (DSM 13054), C. subterraneus subsp. pacificus (DSM 12653), C. subterraneus subsp. tengcongensis (DSM 15242), and Caldanaerobacter uzonensis (DSM 18923). All cultivations were conducted at $\mathrm{pH}$ 7.0 at the organism's $\mathrm{T}_{\mathrm{opt}}$ which is listed in Supplementary Table S1.

All inoculation stocks of the strains were taken from frozen $\left(-20^{\circ} \mathrm{C}\right)$ cultures with rigorously degassed $30 \%(\mathrm{v} / \mathrm{v})$ glycerol and reactivated on BM medium containing glucose $(20 \mathrm{mM})$. Reactivated cultures were inoculated $(2 \% \mathrm{v} / \mathrm{v})$ from exponential growth phase to $25 \mathrm{~mL}$ serum bottles (liquid-gas ratio 1:1). Cultures were grown for 7 days and screened for end-product formation.

\section{Macro Algae Collection and Preparation}

Multi-kilogram quantities of brown algae were collected in the summer of 2015. A. nodosum was obtained from the shores just north of Akureyri, Iceland $\left(65^{\circ} 41^{\prime} 53.31^{\prime \prime} \mathrm{N}, 18^{\circ} 6^{\prime} 32.80^{\prime \prime} \mathrm{W}\right)$ in July of 2015. L. digitata was obtained from a coastal area north of Husavik, Iceland $\left(66^{\circ} 3^{\prime} 38.64^{\prime \prime} \mathrm{N}, 17^{\circ} 21^{\prime} 18.92^{\prime \prime} \mathrm{W}\right)$ in August of 2015. Collected samples were transported to the laboratory and briefly washed with cold tap water; material was then dried in an oven at $45^{\circ} \mathrm{C}$ for $48 \mathrm{~h}$. Dried algae was milled in a Waring blender and then milled to less than $2 \mu \mathrm{m}$ in a Herzog HSM 50 pulverizing mill. The resultant algal meal was stored in air tight containers prior to use.

\section{Extraction of Mannitol From Macro Algae}

The solid-liquid extraction of mannitol from A. nodosum and L. digitata was investigated by varying both temperature $(0,25$, $50^{\circ} \mathrm{C}$ ) and $\mathrm{HCl}$ concentration $(0,50,100 \mathrm{mM})$. One gram of algal meal was placed in a $50 \mathrm{~mL}$ polypropylene tube with $10 \mathrm{~mL}$ of extraction solution $(0,0.05 \mathrm{M}$, or $0.1 \mathrm{M} \mathrm{HCl})$ and mixed at $250 \mathrm{rpm}$ for $15 \mathrm{~min}$ at a $45^{\circ}$ angle to ensure thorough mixing. The supernatant was collected by centrifugation ( $4700 \mathrm{rpm}, 15 \mathrm{~min}$, $4^{\circ} \mathrm{C}$ ). This was repeated for a total of four extraction. Extraction solutions were stored at $-40^{\circ} \mathrm{C}$ prior to analysis for mannitol, total phenolics, and protein.

\section{Extraction Kinetics of Algal Meal}

$10 \mathrm{~g}$ of algal meal was extracted in triplicate on a $10 \mathrm{~g}$ scale with $100 \mathrm{~mL}$ of extraction solution $(50 \mathrm{mM} \mathrm{HCl}$ for A. nodosum or $\mathrm{dH}_{2} \mathrm{O}$ for $L$. digitata) based on results of the previous experiment. Samples were mixed at $250 \mathrm{rpm}$ and supernatant was withdrawn over $15 \mathrm{~min}$ in $3 \mathrm{~min}$ intervals, centrifuged at 13,000 rpm, and stored at $-40^{\circ} \mathrm{C}$ prior to analysis for mannitol, total phenolics, and protein. 


\section{Large-Scale Extraction of Mannitol From Algal Meal}

$100 \mathrm{~g}$ of algal meal was extracted with $1 \mathrm{~L}$ of either $50 \mathrm{mM} \mathrm{HCl}$ (A. nodosum) or $\mathrm{dH}_{2} \mathrm{O}$ (L. digitata) at $200 \mathrm{rpm}$ for $10 \mathrm{~min}$ at $25^{\circ} \mathrm{C}$. The extract was centrifuged at $4700 \mathrm{rpm}$ for $15 \mathrm{~min}$ at $4^{\circ} \mathrm{C}$. $10 \mathrm{~g}$ of $\mathrm{CaCl}_{2}$ was then added to precipitate alginate present and the resultant solution was centrifuged at $4700 \mathrm{rpm}$ at $4^{\circ} \mathrm{C}$ for $15 \mathrm{~min}$. The supernatant solution was adjusted to $\mathrm{pH} 7.0$ with $12 \mathrm{M} \mathrm{NaOH}$ and filtered sequentially through 53 and $5 \mu$ m nylon mesh. Extracts were analyzed for mannitol and total phenolic content.

\section{Screening of Thermophilic Clostridia for Mannitol Utilization}

All strains were screened for mannitol utilization by adding mannitol $(20 \mathrm{mM})$ in Hungate tubes $(16 \mathrm{~mm} \times 150 \mathrm{~mm}$, ChemGlass, United Kingdom) with an L-G ratio of 1:1. Pressure and optical density were determined after 7 days of incubation where after they were analyzed for end products.

\section{Fermentation of Mannitol-Extracts From Macro Algae}

$\mathrm{BM}$ medium was prepared with algal extract diluted to $20 \mathrm{mM}$ mannitol equivalence. Media was prepared in $25 \mathrm{~mL}$ serum bottles. Pressure and optical density were determined after 7 days of incubation where after they were analyzed for end products.

\section{Kinetic Fermentation of Mannitol and Mannitol-Extracts From Macro Algae by T. pseudoethanolicus}

Thermoanaerobacter pseudoethanolicus was cultivated on mannitol (20 $\mathrm{mM})$ and mannitol extracts from macroalgae (equivalent to $20 \mathrm{mM}$ mannitol) in $125 \mathrm{~mL}$ serum bottles. Samples were collected over time for $290 \mathrm{~h}$ with the most intensive sampling at early stage of the fermentations. Samples were analyzed as previously described.

\section{Analytical Methods}

Hydrogen was analyzed using a Perkin Elmer gas chromatograph equipped with thermo conductivity detector as previously described Orlygsson and Baldursson (2007). Volatile fatty acids and alcohols were analyzed by gas chromatograph (Perkin Elmer Clarus 580) using a FID detector with 30 m DB-FFAP capillary column (Agilent Industries Inc., Palo Alto, CA, United States) as previously described Orlygsson and Baldursson (2007). Pressure was determined using a PendoTech PMAT-DPG Handheld PressureMAT. Mannitol was analyzed using the colorimetric method described by Sanchez (1998). Briefly, $25 \mu \mathrm{L}$ of diluted sample (less than $5 \mathrm{mM}$ of mannitol) was added to a microplate to which $125 \mu \mathrm{L}$ of $500 \mathrm{mM}$ formate buffer $(\mathrm{pH} 3.0)$ and $75 \mu \mathrm{L}$ of $5 \mathrm{mM}$ periodic acid. $75 \mu \mathrm{L}$ of freshly prepared reaction solution (100 mM acetylacetone, $2 \mathrm{M}$ ammonium acetate, $20 \mathrm{mM}$ thiosulfate) was added, the plate briefly mixed at $150 \mathrm{rpm}$ and then incubated at $100^{\circ} \mathrm{C}$ on a microplate heating block for $2 \mathrm{~min}$. Samples were then read on a Bioscreen C (Growth Curves
Ltd., Finland) at $412 \mathrm{~nm}$ against a blank prepared as described except substituting reaction solution for distilled water to correct for colored solutions. Standards were prepared from authentic mannitol at a concentration range of $0.5-5 \mathrm{mM}$.

Total phenolic compounds were analyzed colorimetrically by transferring $250 \mu \mathrm{L}$ of sample and $1.25 \mathrm{~mL}$ of $\mathrm{dH}_{2} \mathrm{O}$ to a microtube to which $125 \mu \mathrm{L}$ of Folin-Ciocalteu Reagent was added. After $5 \mathrm{~min}, 375 \mu \mathrm{L}$ of $20 \%(\mathrm{w} / \mathrm{v})$ sodium carbonate was added followed by $500 \mu \mathrm{L}$ of $\mathrm{dH}_{2} \mathrm{O}$ and incubated at ambient temperature for $2 \mathrm{~h}$. Samples were read at $760 \mathrm{~nm}$ on a Shimadzu UV-1800 UV-Visible spectrophotometer in a quartz cuvette $(l=1 \mathrm{~cm})$ against a water blank. Results are calculated as gallic acid equivalent (GAE) using a standard curve prepared from gallic acid standards $(0-100 \mu \mathrm{g} / \mathrm{mL})$.

Lactate was analyzed spectrophotometrically according to Ingvadottir et al. (2017). Bradford protein was analyzed according to (Bradford, 1976) with modifications. $300 \mu \mathrm{L}$ of Bradford reagent was added to a microplate well containing $10 \mu \mathrm{L}$ of sample and shaken for $30 \mathrm{~s}$ at $150 \mathrm{rpm}$ on a microplate shaker. Plates were then read at $600 \mathrm{~nm}$ on a Bioscreen $\mathrm{C}$ (Growth Curves Ltd., Finland) against a water blank. Bovine Serum Albumin was $(0.1-1.25 \mathrm{mg} / \mathrm{mL})$ was used as a standard.

Conductivity was determined using a EC 300 portable conductivity meter (YSI Environmental, United States). Viscosity was measured using a Brookfield DV-II+ Pro EXTRA Programmable Rheometer. Proximate analysis of biomass (protein, fat, ash, and carbohydrate content) was conducted according to standard methods.

\section{RESULTS}

Two types of macroalgal biomass were used in present study to investigate its mannitol content and its extraction. The mannitol present in the macroalgal extracts were then tested as a substrate for six genera of thermophilic bacteria.

\section{Proximate Analysis of Macro Algae}

The two macro algae species used in the present investigation A. nodosum and L. digitata were analyzed for protein, fat, ash, and total carbohydrates. The bulk of the material was greater than $70 \%(\mathrm{dw})$ for both algae although the protein and fat content of A. nodosum were higher as compared to L. digitata but ash and carbohydrate content of the latter were higher (Table 1).

TABLE 1 | Proximate analysis of $A$. nodosum and $L$. digitata collected from Akureyri and Husavik, Iceland, respectively.

\begin{tabular}{|c|c|c|}
\hline & \multicolumn{2}{|c|}{ Brown algae species } \\
\hline & A. nodosum & L. digitata \\
\hline Protein & $6.94 \pm 0.32$ & $4.03 \pm 0.97$ \\
\hline Ash & $15.60 \pm 1.32$ & $18.07 \pm 1.07$ \\
\hline Fat & $5.21 \pm 0.69$ & $0.46 \pm 0.24$ \\
\hline Carbohydrates & $72.24 \pm 0.92$ & $77.43 \pm 0.98$ \\
\hline
\end{tabular}

Values represent the average of triplicate measurements $\pm S D$. 


\section{Extraction of Mannitol From Macroalgae Ascophyllum nodosum}

Mannitol was extracted from $A$. nodosum with three different concentrations of acid $(0,50$, and $100 \mathrm{mM})$, at three temperatures $\left(0,25\right.$, and $\left.50^{\circ} \mathrm{C}\right)$ for four consecutive times. This was also done for protein and total phenolic content (as GAE). The total amounts of mannitol extracted from this macroalgae varied from 7.95 to $39.6 \mathrm{mM}$ (Figure 1A). When end concentrations of mannitol extracted are compared with mannitol concentrations obtained after the first extraction, most often more than 50\% of mannitol was extracted in this first round (range from $47.2 \%\left(0^{\circ} \mathrm{C}, 0.1 \mathrm{M}\right)$ to $68.5 \%\left(25^{\circ} \mathrm{C}, 0.1 \mathrm{M}\right)$ (Figure $1 \mathrm{~A}$ and Supplementary Table S2). Temperature has a clear effect on the amount of mannitol released, with the lowest amounts always found at $0^{\circ} \mathrm{C}$ and highest at $25^{\circ} \mathrm{C}$. Similarly, the effect of acid was profound with little mannitol released without acid but little difference was observed between 50 and $100 \mathrm{mM} \mathrm{HCl}$. Protein extraction from A. nodosum is shown in Figure 1B. The amount of protein extracted ranged from 0.19 to $0.23 \mathrm{mg} / \mathrm{mL}$ with the highest protein amounts observed when the samples were extracted with distilled water at ambient temperature $(0.23 \mathrm{mg} / \mathrm{mL})$. Temperature did not greatly impact the amount of protein solubilized during mannitol extraction (Supplementary Table S3). The content of phenolic compounds were also analyzed for $A$. nodosum under these same conditions (Figure 1C). The only difference with regard to temperature and the concentration of $\mathrm{HCl}$ is that lower amounts of phenolic compounds were extracted at $0^{\circ} \mathrm{C}$ as compared with higher temperatures with and without acid addition (Supplementary Table S4).

\section{Laminaria digitata}

Mannitol extraction from $L$. digitata resulted in much higher concentrations (ranging from 71.3 to $86.9 \mathrm{mM}$ ) as compared with $A$. nodosum (Figure 2A). First extraction always resulted in more than $50 \%$ mannitol extraction when compared with the total amounts extracted (Supplementary Table S5). Interestingly, much less variation was found between the use of $\mathrm{HCl}$ and temperature as compared with $A$. nodosum. Protein extraction from $A$. nodosum were highest at $50^{\circ} \mathrm{C}$ with 50 and $100 \mathrm{mM} \mathrm{HCl}$

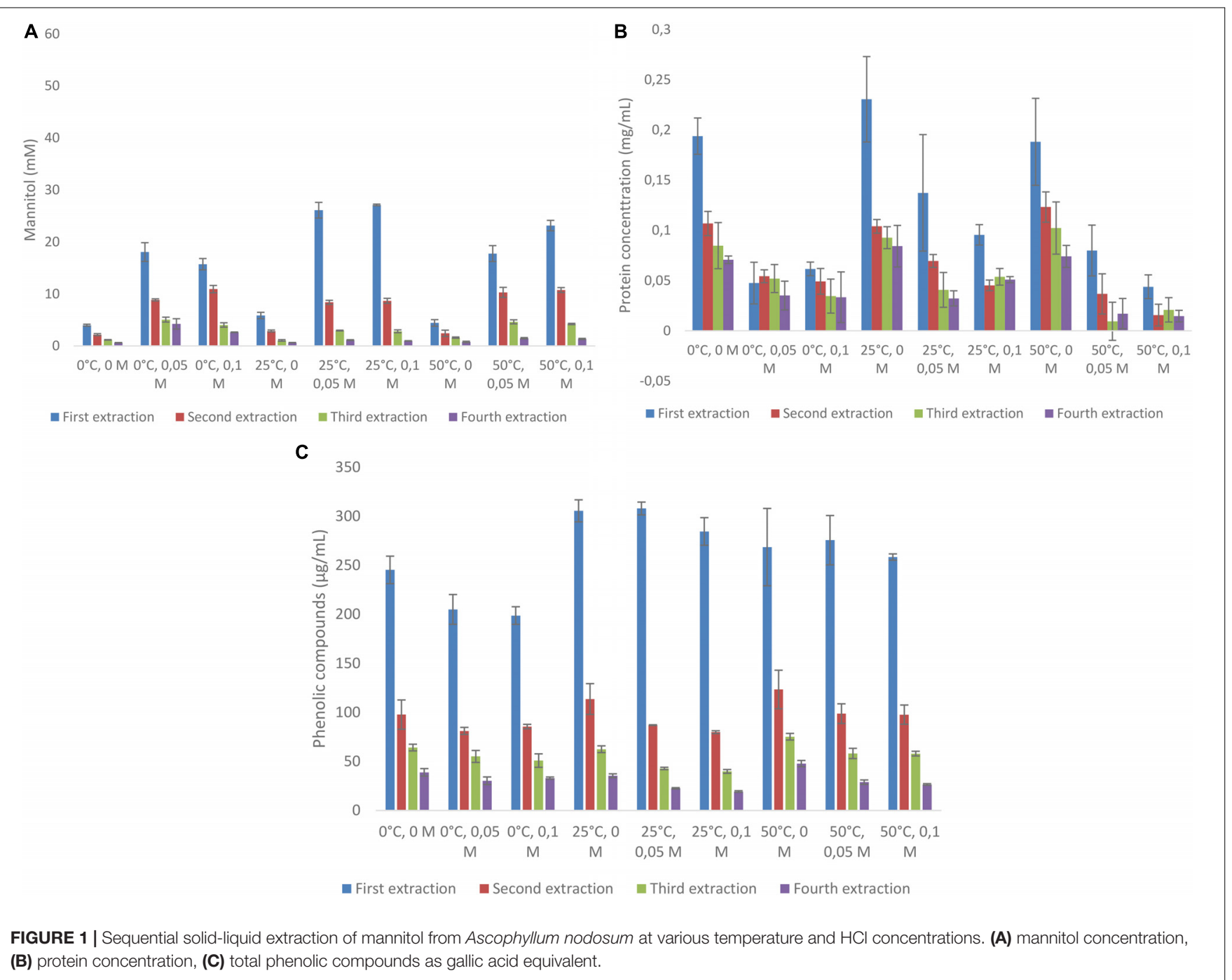




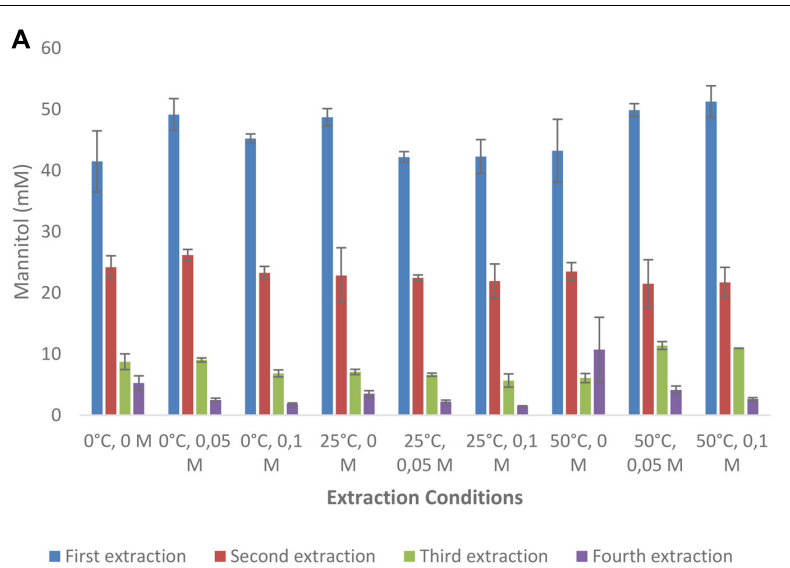

C

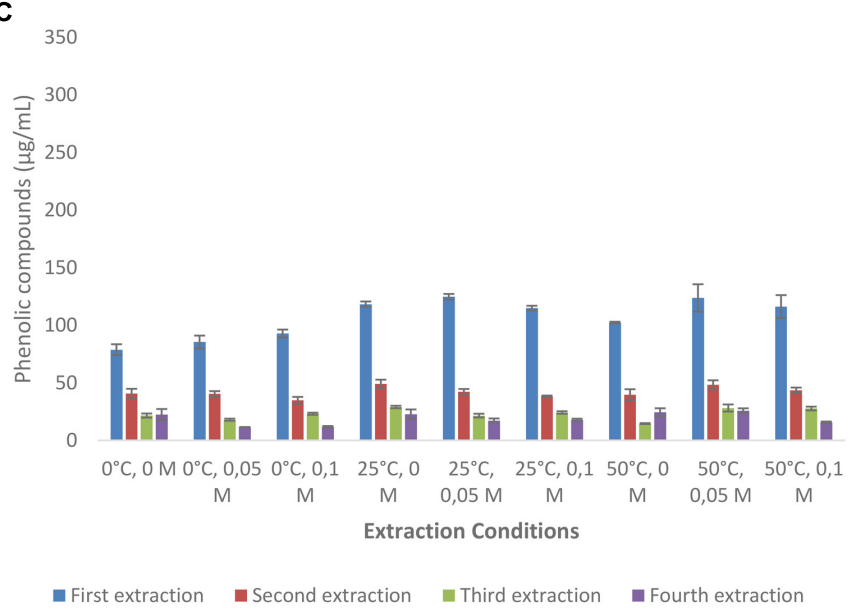

B 0,35

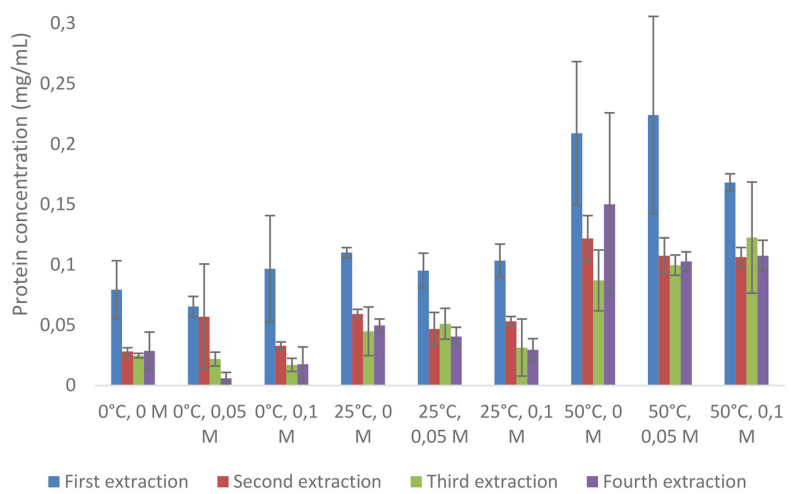

FIGURE 2 | Sequential solid-liquid extraction of mannitol from Laminaria digitata at various temperature and $\mathrm{HCl}$ concentrations. (A) Mannitol concentration, (B) protein concentration, (C) total phenolic compounds as gallic acid equivalent.

concentrations $(0.21-0.22 \mathrm{mg} / \mathrm{mL})$. Much lower concentrations of protein was extracted at other conditions (Figure 2B). The concentrations of phenolic compounds from A. nodosum (Figure 2C) were much lower as compared with $L$. digitata and little difference was between different experimental set up.

\section{Extraction Kinetics of Mannitol and Phenolics From Macroalgal Meal}

In one set of experiments the extraction of both mannitol and phenolic compounds was done kinetically with samples taken every $3 \mathrm{~min}$ for $15 \mathrm{~min}$. Conditions chosen were $25^{\circ} \mathrm{C}$ and $50 \mathrm{mM} \mathrm{HCl}$. Figures $\mathbf{3 A}, \mathbf{B}$ shows that most of the mannitol and phenolic compounds are extracted during the first 3 min of the experiments (more than $75 \%$ of the total quantity extracted). As before, mannitol extraction for $L$. digitata were more than twice of that of A. nodosum and the concentrations of phenolic compounds were 50\% lower (Supplementary Tables S6, S7).

\section{Large Scale Extraction (100 g Scale)}

The preparative scale extraction of mannitol from macro algal meal was conducted on a $100 \mathrm{~g}$ scale using the optimum conditions $\left(25^{\circ} \mathrm{C}, 50 \mathrm{mM} \mathrm{HCl}\right)$ for each brown algae based on previous experiments as summarized in Table 2. As before, the first extraction from both algal meal yielded the highest concentrations of mannitol (19.91 and $65.15 \mathrm{mM}$, from A. nodosum and $L$. digitata, respectively). To reduce the viscosity, $\mathrm{CaCl}_{2}$ was added to precipitate any co-extracted alginate.

\section{Screening of Thermophilic Clostridia for Mannitol Utilization}

Forty one strains of thermophilic clostridia were screened for the degradation and end product formation from $20 \mathrm{mM}$ of mannitol. Most of the strains that were positive on mannitol utilization belong to the genus Thermoanaerobacter. Positives within each genera were Caldanaerobacter (1 of 5 species), Caldicellulosiruptor (2 of 9, both weakly positive), Thermoanaerobacter (7 of 16), and Thermoanaerobacterium ( 1 of 7). T. celere, and Caldanaerobius strains did not utilize mannitol (Table 3). End products of mannitol fermentation are presented in Table 3.

Four of Thermoanaerobacter strains are highly ethanologenic producing more than $30 \mathrm{mmol}$ of ethanol from $20 \mathrm{mM}$ of mannitol but the other three produce between 19.7 and $26.8 \mathrm{mM}$. Other products were lactate, acetate and hydrogen. Only one 


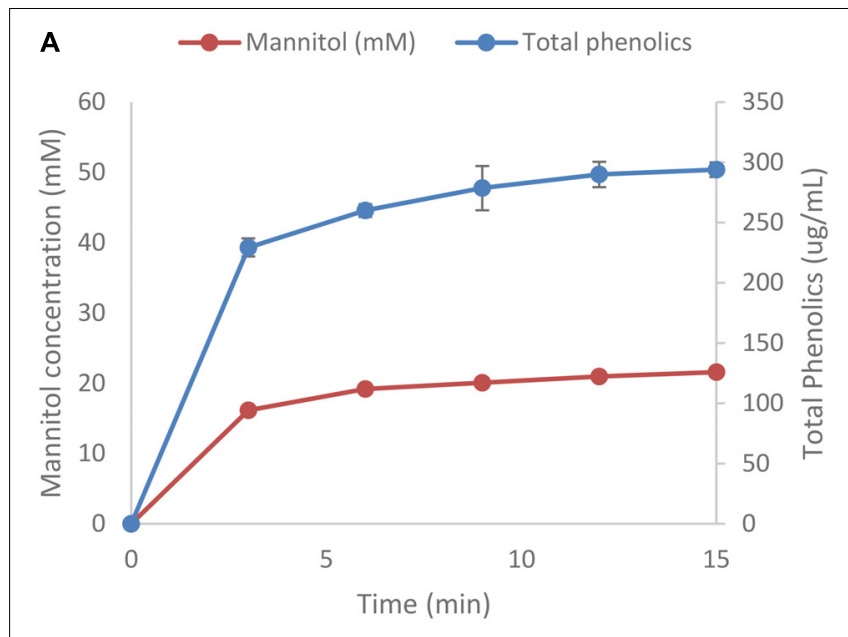

B $\quad \longrightarrow$ Mannitol $(\mathrm{mM}) \quad \longrightarrow$ Total phenolics

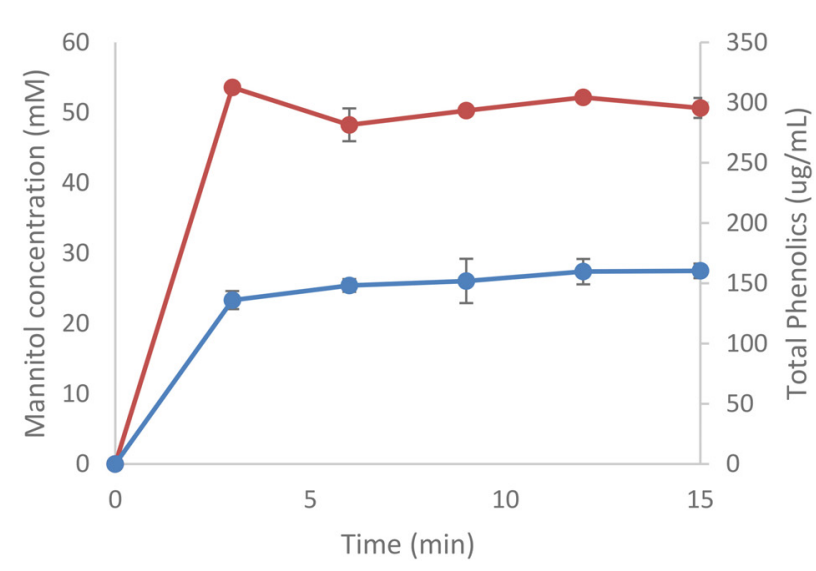

FIGURE 3 | Extraction of mannitol from Ascophyllum nodosum (A) and Laminaria digitata (B). Protein was less then $0.2 \mathrm{mg} / \mathrm{mL}$ (data not shown).

strain, C. subterraneus subsp. pacificus, was found positive of the five Caldanaerobacter species but produced less ethanol as compared to Thermoanaerobacter species. Also, only one of the Thermoanaerobacterium strain was found positive, Th. xylanolyticum producing $18.2 \mathrm{mM}$ of ethanol, $2.7 \mathrm{mM}$ of acetate, and $3.8 \mathrm{mM}$ of lactate. Two of the Caldicellulosiruptor species were weakly positive on mannitol degradation produced low amounts of all end products but above controls.

\section{Fermentation of Macroalgal Extracts by Selected Strains}

Strains demonstrating end product formation on mannitol were then grown on extracts of $A$. nodosum and $L$. digitata diluted to a concentration equivalent to $20 \mathrm{mM}$ of mannitol as shown in Figures 4A,B, respectively. The only strains showing end-product formation from the extracts belong to the genus of Thermoanaerobacter.

Five species (T. siderophilus, T. pseudoethanolicus, T. brockii subsp. finnii, T. brockii subsp. brockii, and T. sulfurigignens) produced considerable amounts of ethanol from both macroalgae species (Figures 4A,B). T. uzonensis however, only produced ethanol on A. nodosum hydrolysate. Ethanol yields (assuming that the only carbon source is mannitol) on the A. nodosum extract ranged from $52.5 \%$ (T. sulfurigignens) to $92.3 \%$ (T. pseudoethanolicus) and fermentation of the L. digitata extract yielded between $52.1 \%$ (T. sulfurigignens) and $67.6 \%$ (T. pseudoethanolicus) of the theoretical yield.

\section{Kinetic Experiment}

One of the strains yielding high ethanol yields on mannitol and macroalgal extracts was T. pseudoethanolicus (Table 4). To further investigate mannitol fermentation by this bacterium, kinetic experiments were conducted on glucose and mannitol, as well as the algal extracts from A. nodosum and L. digitata. Supplementary Figure S1 shows that glucose is rapidly fermented to ethanol by T. pseudoethanolicus reaching $35 \mathrm{mM}$ (87.5\% of theoretical) around $48 \mathrm{~h}$. For comparison, fermentation without added carbon source is presented in Supplementary Figure S2. The fermentation of mannitol (Figure 5A), however, shows the production profile of end-products revealing a rather rapid growth rate and most of the ethanol was already produced within $110 \mathrm{~h}$ (final concentration was $28.1 \mathrm{mM}$ which is slightly lower as compared with the screening data on mannitol). Interestingly most of the ethanol is produced after the bacterium reaches stationary growth phase. As previously, the other minor products were acetate, lactate, and hydrogen. During growth on Laminaria and Ascophyllum extracts similar results were obtained (Figures 5B,C) with ethanol being the main end product and acetate and hydrogen were observed below $10 \mathrm{mmol} / \mathrm{L}$.

\section{DISCUSSION}

\section{Chemical Composition and Extraction of Mannitol From Macroalgae Biomass}

The middle of summer was selected for the sampling period as previous work has shown that the mannitol content peaks around this time in other locations (Adams et al., 2011). While seasonal variation studies on the composition of brown macro algae have not been reported in Iceland, the observed values for protein, fat, and ash were within the ranges previously reported (Indergaard and Minsaas, 1991 and references therein). The bulk of both A. nodosum and L. digitata collected were carbohydrates ( $>70 \%$ on a dry weight basis) with a large ash fraction (Table 1). The collected $L$. digitata contained less than $1 \%$ fat which is lower than the range commonly reported but could potentially be attributed to a relatively low quantity of material extracted (approximately $10 \mathrm{~g}$ ).

Mannitol is an inexpensive carbon source readily extracted from brown macro algae under mild conditions (Figures 1A, 2A). Increasing the length of the extraction may result in the co-extraction of phenolics (Figures 1C, 2C) which could potentially be inhibitory to fermentative organisms (Daglia, 2012). Relative to the amount of protein present in the algal meal $(4-7 \% \mathrm{w} / \mathrm{w})$, relatively low quantities $(<0.2 \mathrm{mg} / \mathrm{mL})$ were extracted under most conditions examined in the present 
TABLE 2 | Preparative scale extraction of mannitol from brown macro algae.

\begin{tabular}{|c|c|c|c|c|c|}
\hline Macro algae & Extraction no. & Mannitol (mM) & Total phenolics ( $\mu \mathrm{g} / \mathrm{mL})$ & Salt (ppt) & Viscosity (cP) \\
\hline \multirow[t]{3}{*}{ A. nodosum } & 1 & $19.91 \pm 0.25$ & $267.87 \pm 0.76$ & 7.4 & 1950.0 \\
\hline & 2 & $8.02 \pm 0.09$ & $114.64 \pm 0.5$ & 4.9 & 24.0 \\
\hline & Total & 27.93 & 382.51 & & \\
\hline \multirow[t]{3}{*}{ L. digitata } & 1 & $65.16 \pm 0.52$ & $125.42 \pm 2.20$ & 11.2 & 4580.0 \\
\hline & 2 & $26.12 \pm 0.03$ & $65.01 \pm 9.18$ & 7.3 & 1620.0 \\
\hline & Total & 91.28 & 190.43 & & \\
\hline
\end{tabular}

All values represent triplicate analyses of single extraction solutions with SD presented as error bars.

TABLE 3 | End product formation from strains degrading mannitol (20 mM).

End products (mmol/L)

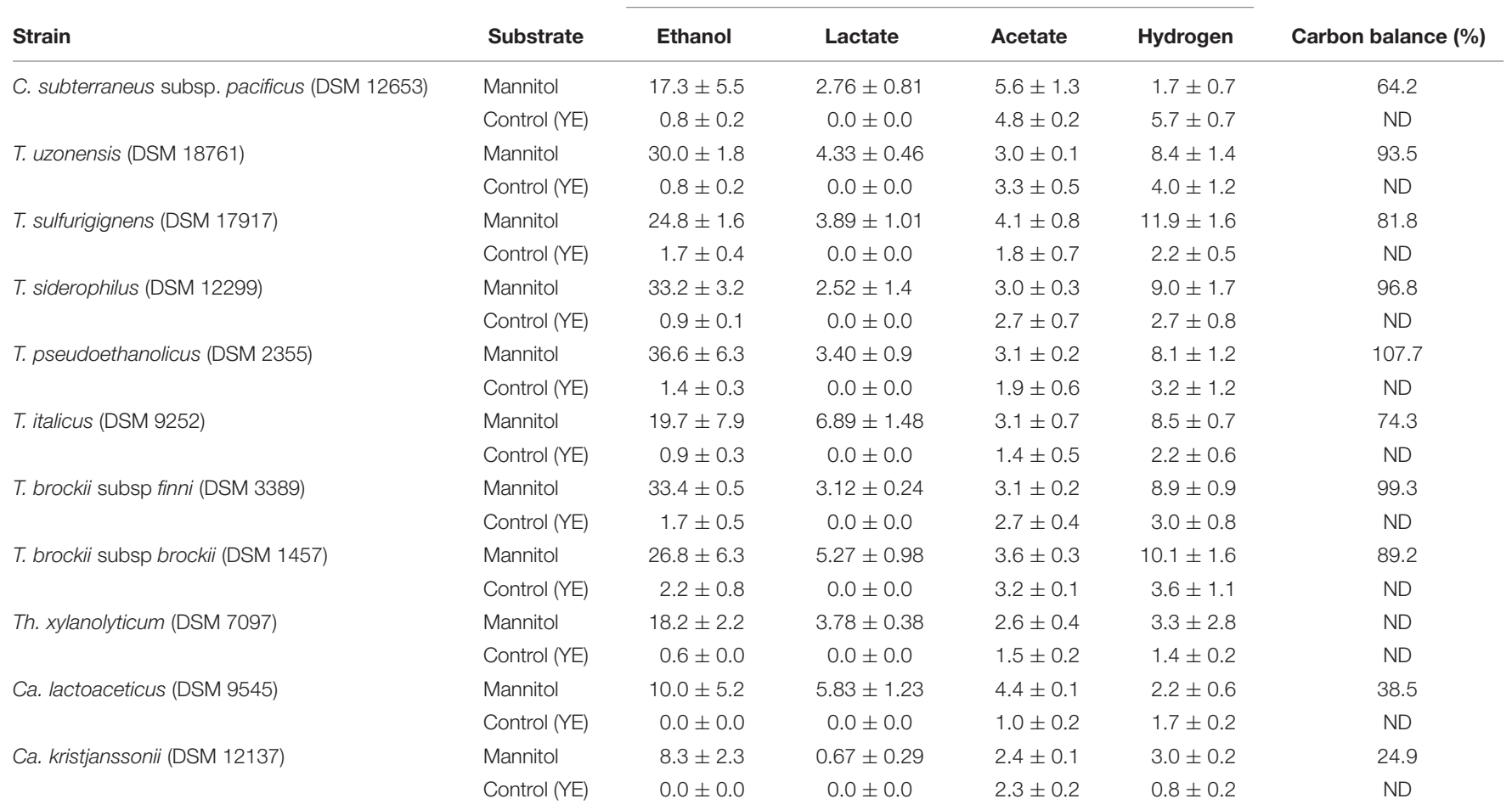

Values represent the average of triplicate measurements \pm SD. C, Caldanaerobacter; T, Thermoanaerobacter; Th, Thermoanaerobacterium; Ca, Caldicellulosiruptor.

investigation (Figures 1B, 2B). The main reason for this difference could be the fact that the proteins present have limited solubility under these conditions or are bound to other components in the matrix. Furthermore, other algal polymers, such as laminarin, fucoidan, alginate, and agar could be co-extracted although this can likely be minimized by using mild conditions and short extraction times as the traditional methodologies for the extraction of these carbohydrates necessitates hot acid extraction (Black et al., 1952; Mateus et al., 1977). For the selective extraction of mannitol, the use of other mineral acids, such as sulfuric acid, maybe more relevant due to $\mathrm{HCl}$ 's volatility, especially at elevated temperatures. Kinetic experiments of mannitol extraction under selected conditions reveal that mannitol is rapidly extracted with peak concentrations for the first and second rounds of extraction being achieved in less than 5 min (Figures $3 \mathbf{A}, \mathbf{B}$ ).
This is more rapid than mannitol extraction reported for other species such as Macrocystis pyrifera (Mateus et al., 1977).

In order to reduce the viscosity after large-scale extraction, an extra step involving the addition of calcium chloride to precipitate the alginate was added. This did not adversely affect the concentration of mannitol although increasing the salinity of the solution may adversely affect a number of the organisms being studied.

\section{Screening of Thermophilic Clostridia for Mannitol Utilization}

The utilization of mannitol is not routinely reported in characterization papers for most thermophilic Clostridia although the type strains of Caloramator were not included in this study, Caloramator boliviensis and Caloramator 


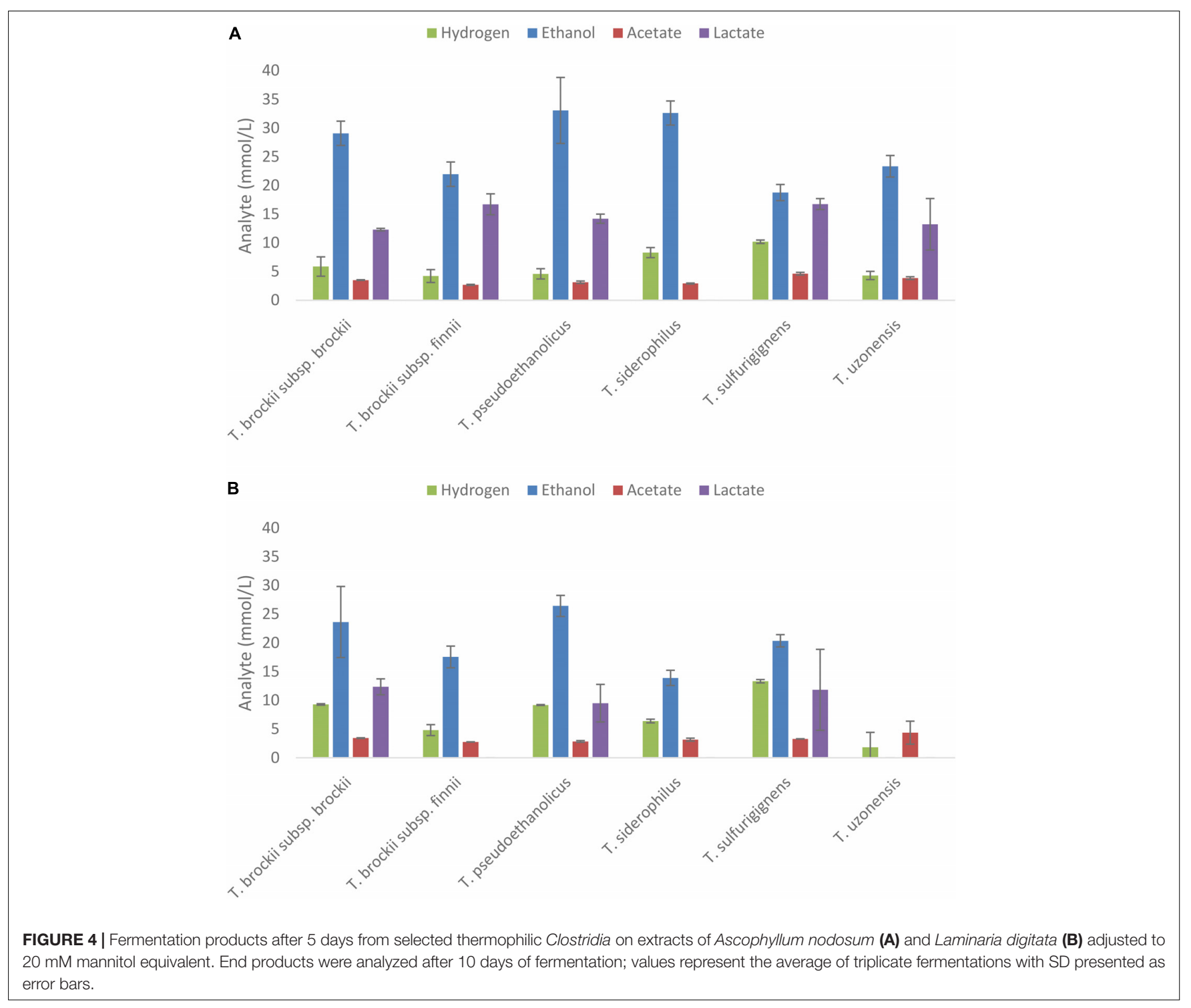

quimbayensis have been noted to utilize mannitol (Crespo et al., 2012; Rubiano-Labrador et al., 2013).

From the data presented the general trend seems to be that mannitol utilization is largely restricted to the genera of Thermoanaerobacter although some strains within Caldicellulosiruptor demonstrated weakly positive results evidenced by low ethanol yields (Table 3). Generally, the mannitol utilization results reported here are in good agreement with the results which have been previously reported with a few exceptions. The subspecies of $C$. subterraneus have been reported to degrade mannitol qualitatively (Fardeau et al., 2004 and references therein) while in this study only C. subterraneus subsp. pacificus degrades mannitol with ethanol as the major end product. Furthermore, T. pentosaceus was originally reported to utilize mannitol although our results are negative.

Four of the Thermoanaerobacter species produce more than $0.4 \mathrm{~g}$ ethanol/g mannitol in the present investigation of which the maximum theoretical yields are $0.51 \mathrm{~g}$ ethanol $/ \mathrm{g}$ mannitol
( $1.5 \mathrm{~mol}$ ethanol/mol mannitol). This is comparable with several mesophilic bacteria like Escherichia coli and Zymobacter palmae which have been reported to produce 0.41 and $0.38 \mathrm{~g} / \mathrm{g}$, respectively (Horn et al., 2000; Kim et al., 2011). Other mesophilic microorganism have been reported to produce lower amounts of ethanol, such as Enterobacter sp., Pichia angophorae, and Vibrio tritonius AM2, with $0.29,0.29$, and $0.36 \mathrm{~g}$ ethanol/g substrate, respectively. The thermophilic bacterium belonging to Class Clostridia, Defluviitalea phaphyphila, has recently been shown to produce high ethanol titers from mannitol with yields of up to $0.44 \mathrm{~g} / \mathrm{g}$ being reported (Ji et al., 2016a,b).

\section{Fermentation of Mannitol in Macroalgal Extracts by Selected Strains}

Despite positive growth and end product formation on mannitol, strains from the genera of Caldicellulosiruptor, Caldanaerobacter, and Thermoanaerobacterium did not utilize 


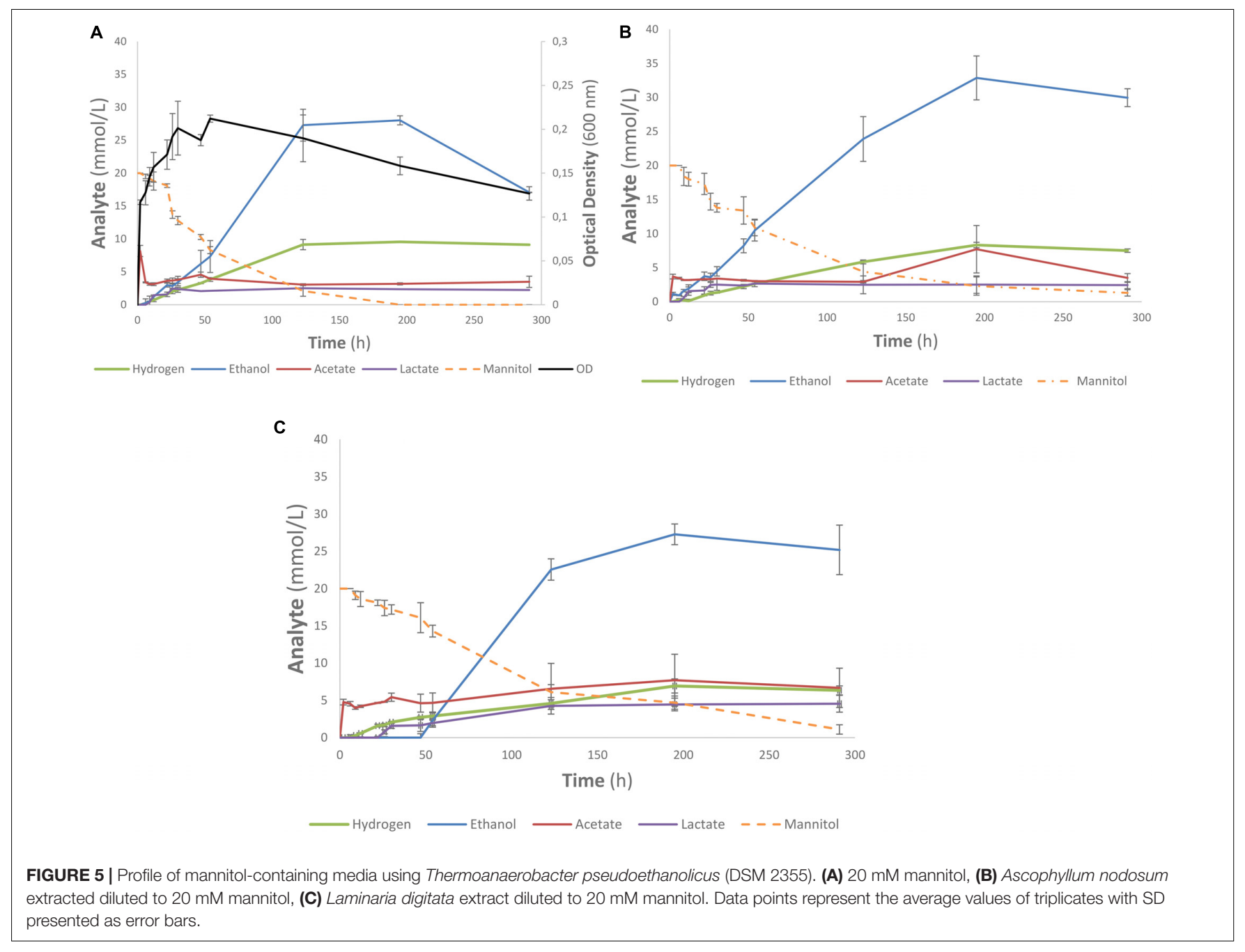

the mannitol-containing extracts from A. nodosum or L. digitata. The five mannitol-degrading strains of Thermoanaerobacter yielded good ethanol yields from the macro algal extracts, the highest ethanol concentration, $33.1 \mathrm{mM}$ were obtained from T. pseudoethanolicus on A. nodosum extracts. In general higher ethanol yields were obtained on Ascophyllum extracts (between 18.8 and $33.1 \mathrm{mM}$ ) compared to Laminaria extracts (0.0-26.4 mM). Assuming that mannitol is the only sugar left in the extracts after extraction the ethanol yields are in good correlation with ethanol yields from mannitol only (Figures 4A,B). Several studies have been performed using various types of macro algae for ethanol production. When the recently isolated thermophile Defluviitalea phaphyphila was cultivated on the alginates from the brown macroalgae Saccharina japonica the bacterium produced $2.7 \mathrm{~g}$ of ethanol and $3.0 \mathrm{~g}$ of acetate from $7.6 \mathrm{~g}$ of alginate (Ji et al., 2016a,b). The study by Matsumura et al. (2014) on the brown macroalgae Saccharina sculpera using the facultative anaerobe Vibrio tritonius resulted in production of $11.5 \mathrm{~g}$ of ethanol from $30 \mathrm{~g}$ of seaweed hydrolysate. In a study with E. coli cultivated on enzyme pretreated hydrolysate of $L$. japonica the maximum ethanol production observed was $0.29 \mathrm{~g} / \mathrm{g}$ biomass (Kim et al., 2011). Finally, Saccharomyces cerevisiae has been reported to produce between 4 and $5 \mathrm{~g} / \mathrm{L}$ of ethanol in a SSF fermentation of

TABLE 4 | Features of kinetic experiments with Thermoanaerobacter pseudoethanolicus (DSM 2355) on mannitol and macro algal extracts.

\begin{tabular}{lcccc}
\hline & & \multicolumn{2}{c}{ Ethanol yield } \\
\cline { 3 - 5 } Substrate & Fermenation time (h) & Yield (\%) & Ethanol (g/g substrate) & Volumetric productivity (mM per hour) \\
\hline Mannitol & 123 & 70.1 & 0.36 & 0.29 \\
A. nodosum extract & 195 & 82.2 & 0.42 & 0.22 \\
L. digitata extract & 195 & 68.2 & 0.35 & 0.33
\end{tabular}


S. japonica (Li et al., 2013). It is difficult to compare these results since the concentration of the extracts used, species type and pretreatment methods used vary to a great extent. Clearly however, the best Thermoanaerobacter species producing more than $30 \mathrm{mM}$ of ethanol from macroalgal extracts containing $20 \mathrm{mM}$ of mannitol are among the higher yields observed in literature with other microorganism.

As the end products were analyzed after 5 days, it is possible that some strains could exhibit delayed ethanol formation as observed in the kinetic experiments with T. pseudoethanolicus on both $20 \mathrm{mM}$ mannitol and the brown algal extracts adjusted to $20 \mathrm{mM}$ of mannitol. Furthermore, the lack of observed end product formation on mannitol-containing algal extracts could be due to inhibition phenomena from co-extracted salts or other inhibitory compounds. The salt concentrations in the macroalgal extracts in our study was 0.5 and $1.1 \%$ (Table 2). While salt tolerance has not been widely investigated for the type strains of these genera although some data on Caldicellulosiruptor species have been reported; $C$ a kristjansson is inhibited below $0.2 \% \mathrm{NaCl}$, $\mathrm{Ca}$. acetigenus is inhibited at $0.2 \%$ while many other members of the genus only tolerate up to $1 \%$ (Onyenwoke et al., 2006; Bing et al., 2015).

\section{Kinetic Studies of Anntiol and Algal Extract Fermentation}

Fermentation of mannitol by $T$. pseudoethanolicus is comparatively slow compared to other substrates (such as glucose, Supplementary Figure S1) only reaching a maximum ethanol after $120 \mathrm{~h}$ (Figure 5A). Ethanol formation continued into the stationary phase which could indicate a bottleneck in feeding mannitol catabolism intermediates into glycolysis pathway. Further work is needed to understand the nature of mannitol utilization by T. pseudoethanolicus and to explain why the formation of reduced end products is slower as compared with glucose. It is worth noting that optical density of the culture was approximately $30 \%$ higher on glucose as compared with mannitol and three times as high compared with control (yeast extract only) (Supplementary Figures S1, S2 and Figure 5A). The fermentation of the mannitol-containing algal extracts were more slowly fermented to ethanol than with mannitol only (Figures 5B,C). The mannitol may have been less accessible to the microorganism due to other compounds in the sample matrix. The optical density was not measured during these fermentations due to the highly turbid nature of the algal extracts. Additionally, fermentation of other compounds present in the extract such as laminarin are possible since some Clostridia have been reported to have glucosidases capable of cleaving a $\beta-1,3-O$ glycosidic bond although this capability has not been systematically investigated (Leschine, 2005). As the end product were analyzed after 5 days, it is possible that some strains exhibited delayed ethanol formation as observed in the kinetic experiments with T. pseudoethanolicus on both $20 \mathrm{mM}$ mannitol and the brown algae extracts adjusted to $20 \mathrm{mM}$ of mannitol. Furthermore, the lack of observed end product formation on mannitol-containing algae extracts could be due inhibition phenomena from co-extracted salts or other inhibitory compounds.
The slow degradation of mannitol by T. pseudoethanolicus could be problematic for commercialization of bioethanol production from macro algae. This could potentially be overcome by increasing the cell density by immobilization, by using continuous culture, as well as the optimization of culture conditions, and genetic engineering of the strain. Furthermore, the utilization of other components of brown macro algae, such as laminarin and alginate, could be approached by hydrolyzing the macro algae using commercially available enzymes. Also, hydrolysates prepared from species known to degrade these polysaccharides could lead to a greater utilization of the biomass perhaps using a cascading biorefinery scheme that couples the removal of higher-value products to the fermentation of lower value fractions such as mannitol.

\section{CONCLUSION}

Mannitol is a potentially viable source of carbon for the fermentative production of bioethanol by thermophilic anaerobes isolated from diverse environments. Mannitol can be rapidly extracted from $A$. nodosum and $L$. digitata under mild conditions with good yields. The amount of mannitol released from the two species of brown macroalgae varied to a great extent; always lower than $40 \mathrm{mM}$ from $A$. nodosum but higher than $72 \mathrm{mM}$ from $L$. digitata. The amount of protein and phenolic compounds released were also different between macroalgae species (about $300 \mu \mathrm{g} / \mathrm{mL}$ for $A$. nodosum and $100 \mu \mathrm{g} / \mathrm{mL}$ for L. digitata). Of 41 thermophilic Clostridia species tested for mannitol utilization, 11 were positive mainly species within the genus Thermoanaerobacter. Four species showed more than $75 \%$ ethanol yields on the sugar alcohol. Six Thermoanaerobacter species degraded macroalgal extracts resulting in ethanol as the main end-product. T. pseudoethanolicus was the best ethanol producer both from pure mannitol as well as from macroalgae biomass.

\section{AUTHOR CONTRIBUTIONS}

EI, SS, and TC designed and performed the experiments and analysis. SS and JO drafted the manuscript.

\section{FUNDING}

This work was supported by AVS research fund, grant R15 065-15. The project was funded by AVS (Aukið verðmæti sjávarafurða), an Icelandic Research Funding which is not listed in the Funding body above.

\section{SUPPLEMENTARY MATERIAL}

The Supplementary Material for this article can be found online at: https://www.frontiersin.org/articles/10.3389/fmicb. 2018.01931/full\#supplementary-material 


\section{REFERENCES}

Adams, J. M. M., Ross, A. B., Anastasakis, K., Hodgson, E. M., Gallagher, J. A., Jones, J. M., et al. (2011). Seasonal variation in the chemical composition of the bioenergy feedstock Laminaria digitata for thermochemical conversion. Bioresour. Technol. 102, 226-234. doi: 10.1016/j.biortech.2010.06.152

Bing, W., Wang, H., Zheng, B., Zhang, F., Zhu, G., Feng, Y., et al. (2015). Caldicellulosiruptor changbaiensis sp. nov., a cellulolytic and hydrogenproducing bacterium from a hot spring. Int. J. Syst. Evol. Microbiol. 65, 293-297. doi: 10.1099/ijs.0.065441-0

Black, W. A. P., Dewar, E. T., and Woodward, F. N. (1952). Manufacture of algal chemicals. IV.-laboratory-scale isolation of fucoidin from brown marine algae. J. Sci. Food Agric. 3, 122-129. doi: 10.1002/jsfa.2740030305

Blumer-Schuette, S. E., Giannone, R. J., Zurawski, J. V., Ozdemir, I., Ma, Q., Yin, Y., et al. (2012). Caldicellulosiruptor core and pangenomes reveal determinants for noncellulosomal thermophilic deconstruction of plant biomass. J. Bacteriol. 194, 4015-4028. doi: 10.1128/JB.00266-12

Bouanane-Darenfed, A., Fardeau, M.-L., Greégoire, P., Manon, J., KebboucheGana, S., Benayad, T., et al. (2011). Caldicoprobacter algeriensis sp. nov. a new thermophilic anaerobic, xylanolytic bacterium isolated from an algerian hot spring. Curr. Opin. Microbiol. 62, 826-832. doi: 10.1007/s00284-010-9789-9

Bradford, M. M. (1976). A rapid and sensitive method for the quantitation of microgram quantities of protein utilizing the principle of protein-dye binding. Anal. Biochem. 72, 248-254. doi: 10.1016/0003-2697(76)90527-3

Burgess, E. A., Wagner, I. C., and Wiegel, J. (2007). "Thermophile environments and biodiversity," in Physiology and Biochemistry of Extremophiles, eds C. Gerday and N. Glansdorff (Washington, DC: ASM Press), 13-29. doi: 10.1128/ 9781555815813.ch2

Carere, C. R., Rydzak, T., Verbeke, T. J., Cicek, N., Levin, D. B., and Sparling, R. (2012). Linking genome content to biofuel production yields: a meta-analysis of major catabolic pathways among select $\mathrm{H} 2$ and ethanol-producing bacteria. BMC Microbiol. 12:295. doi: 10.1186/1471-2180-12-295

Chang, T., and Yao, S. (2011). Thermophilic, lignocellulolytic bacteria for ethanol production: current state and perspectives. Appl. Microbiol. Biotechnol. 92, 13-27. doi: 10.1007/s00253-011-3456-3

Cook, G. M., Rainey, F. A., Patel, B. K. C., and Morgan, H. W. (1996). Characterization of a new obligately anaerobic thermophile, Thermoanaerobacter wiegelii sp. nov. Int. J. Syst. Bacteriol. 46, 123-127. doi: 10.1099/00207713-46-1-123

Crespo, C., Pozzo, T., Karlsson, E. N., Alvarez, M. T., and Mattiasson, B. (2012). Caloramator boliviensis sp. nov., a thermophilic, ethanol-producing bacterium isolated from a hot spring. Int. J. Syst. Evol. Microbiol. 62, 1679-1686. doi: 10.1099/ijs.0.032664-0

Daglia, M. (2012). Polyphenols as antimicrobial agents. Curr. Opin. Biotechnol. 23, 174-181. doi: 10.1016/j.copbio.2011.08.007

Daroch, M., Geng, S., and Wang, G. (2013). Recent advances in liquid biofuel production from algal feedstocks. Appl. Energy 102, 1371-1381. doi: 10.1016/ j.apenergy.2012.07.031

Enquist-Newman, M., Faust, A. M. E., Bravo, D. D., Santos, C. N. S., Raisner, R. M., Hanel, A., et al. (2014). Efficient ethanol production from brown macroalgae sugars by a synthetic yeast platform. Nature 505, 239-243. doi: 10.1038/nature12771

Fardeau, M., Salinas, M. B., L'Haridon, S., Jeanthon, C., Verhé, F., Cayol, J., et al. (2004). Isolation from oil reservoirs of novel thermophilic anaerobes phylogenetically related to Thermoanaerobacter subterraneus: reassignment of T. subterraneus, Thermoanaerobacter yonseiensis, Thermoanaerobacter tengcongensis and Carboxydibrachium pacificum. Int. J. Syst. Evol. Microbiol. 54, 467-474. doi: 10.1099/ijs.0.02711-0

Heyndrickx, M., De Vos, P., Speybrouck, A., and De Ley, J. (1989). Fermentation of mannitol by Clostridium butyricum: role of acetate as an external hydrogen acceptor. Appl. Microbiol. Biotechnol. 31, 323-328. doi: 10.1007/BF0025 7597

Horn, S. J., Aasen, I. M., and Ostgaard, K. (2000). Ethanol production from seaweed extract. J. Ind. Microbiol. Biotechnol. 25, 249-254. doi: 10.1038/sj.jim.7000065

Hungate, R. E. (1969). A roll tube method for cultivation of strict anaerobes, in Methods in Microbiology, eds J. R. Norris and D. W. Ribbons (New York, NY: Academic Press), 117-132.
Indergaard, M., and Minsaas, J. (1991). “Animal and human nutrition,” in Seaweed Resources in Europe: Uses and Potential, eds M. D. Guiry and G. Blunden (Chichester: John Wiley \& Sons, Ltd.), 21-64.

Ingvadottir, E. M., Scully, S. M., and Orlygsson, J. (2017). Evaluation of the genus of Caldicellulosiruptor for producation of 1,2-propanediol from methylpentoses. Anaerobe 47, 86-88. doi: 10.1016/j.anaerobe.2017.04.015

Ji, S. Q., Wang, B., Lu, M., and Li, F. L. (2016a). Biotechnology for biofuels direct bioconversion of brown algae into ethanol by thermophilic bacterium Defluviitalea phaphyphila. Biotechnol. Biofuels 9, 1-10. doi: 10.1186/s13068016-0494-1

Ji, S. Q., Wang, B., Lu, M., and Li, F. L. (2016b). Defluviitalea phaphyphila sp. nov., a novel thermophilic bacterium that degrades brown algae. Appl. Environ. Microbiol. 82, 868-877. doi: 10.1128/AEM.03297-15

Jiang, R., Ingle, K. N., and Golberg, A. (2016). Macroalgae (seaweed) for liquid transportation biofuel production: what is next? Algal Res. 14, 48-57. doi: 10.1016/j.algal.2016.01.001

Kaid, N., Al-shorgani, N., Hafez, M., Isa, M., Mohtar, W., Yusoff, W., et al. (2016). Isolation of a Clostridium acetobutylicum strain and characterization of its fermentation performance on agricultural wastes. Renew. Energy 86, 459-465. doi: 10.1016/j.renene.2015.08.051

Kawai, S., and Murata, K. (2016). Biofuel production based on carbohydrates from both brown and red macroalgae: recent developments in key biotechnologies. Int. J. Mol. Sci. 145, 1-17. doi: 10.3390/ijms17020145

Kazamias, M. T., and Sperry, J. F. (1995). Enhanced fermentation of mannitol and release of cytotoxin by Clostridium difficile in alkaline culture media. Appl. Environ. Microbiol. 61, 2425-2427.

Kim, N., Li, H., Jung, K., Nam, H., and Cheon, P. (2011). Ethanol production from marine algal hydrolysates using Escherichia coli KO11. Bioresour. Technol. 102, 7466-7469. doi: 10.1016/j.biortech.2011.04.071

Leschine, S. (2005). "Degradation of polymer: cellulose, xylan, pectin, starch," in Handbook on Clostridia, ed. P. Durre (Boca Raton, FL: CRC Press), 101-131.

Li, P., Lee, J., Jin, H., and Keun, K. (2013). Ethanol production from Saccharina japonica using an optimized extremely low acid pretreatment followed by simultaneous saccharification and fermentation. Bioresour. Technol. 127, 119-125. doi: 10.1016/j.biortech.2012.09.122

Mateus, H., Regenstein, J. M., and Baker, R. C. (1977). Studies to improve the extraction of mannitol and alginic acid from Macrocystis pyrifera, a marine brown algae. Econ. Bot. 31, 24-27. doi: 10.1007/BF02860648

Matsumura, Y., Sato, K., Al-saari, N., Nakagawa, S., and Sawabe, T. (2014). Enhanced hydrogen production by a newly described heterotrophic marine bacterium, Vibrio tritonius strain AM2, using seaweed as the feedstock. Int. J. Hydrogen Energy 39, 7270-7277. doi: 10.1016/j.ijhydene.2014.02.164

Milledge, J. J., Smith, B., Dyer, P. W., and Harvey, P. (2014). Macroalgae-derived biofuel: a review of methods of energy extraction from seaweed biomass. Energies 7, 7194-7222. doi: 10.3390/en7117194

Miller, T. L., and Wolin, M. J. (1974). A serum bottle modification of the Hungate technique for cultivating obligate anaerobes. Appl. Microbiol. 27, 985-987.

Muty, U. S., and Banerjee, A. K. (2012). "Seaweeds: the wealth of oceans," in Handbook of Marine Macroalgae: Biotechnology and Applied Phycology, ed. S.-K. Kim (Hoboken, NJ: Wiley-Blackwell), 36-44.

Onyenwoke, R. U., Lee, Y., Dabrowski, S., Ahring, B. K., and Wiegel, J. (2006). Reclassification of Thermoanaerobium acetigenum as Caldicellulosiruptor acetigenus comb. nov. and emendation of the genus description. Int. J. Syst. Evol. Microbiol. 56, 1391-1395. doi: 10.1099/ijs.0.63723-0

Orlygsson, J., and Baldursson, S. R. B. (2007). Phylogenetic and physiological studies of four hydrogen-producing thermoanareobes. Icel. Agric. Sci. 20, 93-105.

Patil, Y., Junghare, M., Pester, M., and Mu, N. (2015). Anaerobium acetethylicum gen. nov., sp. nov., a strictly anaerobic, gluconate-fermenting bacterium isolated from a methanogenic bioreactor. Int. J. Syst. Evol. Microbiol. 65, 3289-3296. doi: 10.1099/ijsem.0.000410

Quain, D. E., and Boulton, C. A. (1987). Growth and metabolism of mannitol by strains of Saccharomyces cerevisiae. J. Gen. Microbiol. 133, 1675-1684. doi: 10.1099/00221287-133-7-1675

Radulovich, R., Neori, A., Valderrama, D., Reddy, C. R. K., Cronin, H., and Forster, J. (2015). "Farming of seaweeds," in Seaweed Sustainability: Food and Non-Food Applications, eds B. K. Tiwori and D. J. Troy 
(New York, NY: Academic Press), 27-59. doi: 10.1016/B978-0-12-418697-2. 00003-9

Ren, N., Wang, A., Cao, G., Xu, J., and Gao, L. (2009). Bioconversion of lignocellulosic biomass to hydrogen: potential and challenges. Biotechnol. Adv. 27, 1051-1060. doi: 10.1016/j.biotechadv.2009.05.007

Rubiano-Labrador, C., Baena, S., Díaz-Cárdenas, C., and Patel, B. K. C. (2013). Caloramator quimbayensis sp. nov., an anaerobic, moderately thermophilic bacterium isolated from a terrestrial hot spring. Int. J. Syst. Evol. Microbiol. 63, 1396-1402. doi: 10.1099/ijs.0.037937-0

Sanchez, J. (1998). Colorimetric assay of alditols in complex biological samples. J. Agric. Food Chem. 46, 157-160. doi: 10.1021/jf970619t

Sánchez, O. J., and Cardona, C. A. (2008). Trends in biotechnological production of fuel ethanol from different feedstocks. Bioresour. Technol. 99, 5270-5295. doi: 10.1016/j.biortech.2007.11.013

Scully, S., and Orlygsson, J. (2015). Recent advances in second generation ethanol production by thermophilic bacteria. Energies 8, 1-30. doi: 10.3390/en8010001

Sittijunda, S., Tomás, A. F., Reungsang, A., O-thong, S., and Angelidaki, I. (2013). Ethanol production from glucose and xylose by immobilized Thermoanaerobacter pentosaceus at $70{ }^{\circ} \mathrm{C}$ in an up-flow anaerobic sludge blanket (UASB) reactor. Bioresour. Technol. 143, 598-607. doi: 10.1016/j. biortech.2013.06.056

Sveinsdottir, M., Beck, S. R., and Orlygsson, J. (2009). Ethanol production from monosugars and lignocellulosic biomass by thermophilic bacteria isolated from Icelandic hot springs. Icel. Agric. Sci. 22, 45-58.

Tanghe, A., Prior, B., and Thevelein, J. M. (2005). "Yeast responses to stresses," in The Yeast Handbook: Biodiversity and Ecophysiology of Yeasts, eds C. A. Rosa and G. Péter (New York, NY: Springer), 175-195.
Taylor, M. P., Eley, K. L., Martin, S., Tuffin, M. I., Burton, S. G., and Cowan, D. A. (2009). Thermophilic ethanologenesis: future prospects for second-generation bioethanol production. Trends Biotechnol. 27, 398-405. doi: 10.1016/j.tibtech. 2009.03.006

Tomás, A. F., Karakashev, D., and Angelidaki, I. (2013). Thermoanaerobacter pentosaceus sp. nov., an anaerobic, extreme thermophilic, high ethanol-yielding bacterium isolated from household waste. Int. J. Syst. Evol. Microbiol. 63, 2396-2404. doi: 10.1099/ijs.0.045211-0

Wei, N., Quarterman, J., and Jin, Y.-S. (2013). Marine macroalgae: an untapped resource for producing fuels and chemicals. Trends Biotechnol. 31, 70-77. doi: 10.1016/j.tibtech.2012.10.009

Xia, A., Jacob, A., Herrmann, C., Tabassum, M. R., and Murphy, J. D. (2015). Production of hydrogen, ethanol and volatile fatty acids from the seaweed carbohydrate mannitol. Bioresour. Technol. 193, 488-497. doi: 10.1016/j. biortech.2015.06.130

Conflict of Interest Statement: The authors declare that the research was conducted in the absence of any commercial or financial relationships that could be construed as a potential conflict of interest.

Copyright (c) 2018 Chades, Scully, Ingvadottir and Orlygsson. This is an open-access article distributed under the terms of the Creative Commons Attribution License (CC BY). The use, distribution or reproduction in other forums is permitted, provided the original author(s) and the copyright owner(s) are credited and that the original publication in this journal is cited, in accordance with accepted academic practice. No use, distribution or reproduction is permitted which does not comply with these terms. 